\title{
Analysis of the Community's Willingness to Pay (WTP) for the Protection of Mangroves in Kuala Langsa, Aceh
}

\author{
Zuriana Siregar $^{a^{*}}$, Syamsuardi $^{b}$, Azwar Rasyidin $^{b}$ and Eni Kamal $^{c}$ \\ ${ }^{a}$ Universitas Syiah Kuala, Darussalam, Banda Aceh 23111, Aceh, Indonesia, \\ ${ }^{b}$ Universitas Andalas, Kampus Unand Limau Manis, Padang 25163, West Sumatera, Indonesia \\ ${ }^{c}$ Universitas Bung Hatta, Ulak Karang, Padang 25133, West Sumatera, Indonesia
}

\author{
ARTICLE INFORMATION \\ Article history: \\ Received: 26 January 2018 \\ Revised: 13 June 2019 \\ Accepted: 25 July 2019 \\ Keywords: \\ Willingness to pay, mangrove \\ protection, contingent valuation method \\ Correspondence: \\ zuryunsyiah@gmail.com
}

\begin{abstract}
A B S T R A C T
Mangrove, as one of the most unique ecosystems, is a great natural resource potential with high productivity and biodiversity that is able to adapt to harsh areas between the sea and the coast. Its destruction rate is very mild as it is estimated to $1 \%$ each year and $0.7-3 \%$ per year. Mangrove damage is usually related associated with the density of human population Extensive mangrove destruction affects the loss of biodiversity and other resources and the functioning of the ecosystems. The great potential of mangrove must be conserved by managing, maintaining and providing costs to protect and improve ecosystems. This study aims to measure Kuala Langsa community members' willingness to pay for the preservation and repairation of degrading mangrove. To achieve this goal, a contingent valuation methods was used in this study. Of the 131 respondents involved in this study, 112 or $85.496 \%$ respondents were willing to pay for the preservation of mangrove, while those unwilling to pay were account for 19 or $4.504 \%$. WTP with the households 669 earned by was Rp 18,821,512,200/month or Rp $225,858,146,400 /$ year..
\end{abstract}

\section{INTRODUCTION}

Indonesia is believed to have the largest mangrove (in terms of area) in the world which covers about 8.60 million hectares (Gunarto, 2004). Mangroves are commonly found on beaches, shallow bays, estuaries, delta and sheltered beaches like the east coasts of Sumatra, along the coasts of Kalimantan and South Sulawesi and Irian Jaya. Mangroves in Southeast Asia (Indonesia, Malaysia, Singapore, Philippines, Thailand and Brunei Darussalam) account for $40 \%$ of the remaining mangroves forests (Sasekumar et al., 1994).
Mangroves, as one of the most unique ecosystems, is a great natural resource potentials with high productivity and biodiversity that is able to adapt to harsh areas between the sea and the coast. Mangrove ecosystems can provide essential nutrients and organic carbon for tropical easide (Alongi, 1996) and play important roles including balancing ecosystems and providing for diverse needs of humans and other living things creatures.

Mangroves provide great benefits to the coastal environment. But human activity have has dramatically affected them over the last few decades. The mangrove 
degradation rate is estimated to be $1 \%$ annually (Ong et al., 1991), whereas according to Pedleton et al., (2012) mangrove degradation rate of $0.7-3 \% / y e a r$. Mangrove degradation is usually associated with the density of human population (Alongi, 2002). The main causes of mangrove degradation are population growth and rapid development in coastal areas, aquaculture, mining and over-exploitation of timber, fish, crustaceans and shellfish (Alongi, 2002), climate change (Sarhan, 2014) and severe illegal logging during Dutch colonial 16th century (Sukardjo, 1987), as well as limited scientific knowledge of mangrove productivity in its management and utilization (Soemodihardjo and Soerianegara, 1989).

The coastal region of Aceh has been degraded considerably, especially along the east coast. The main causes of degradation are the development of shrimp farms, oil palm plantations, and tmangrove cutting for charcoal. Most of the aquaculture ponds in Aceh Province are mangroves converted into ponds. The conversion of mangroves into shrimp farms has grown to the date and is a major threat to mangroves in many countries (Primavera, 1998). Ironically, the productivity of the aquaculture system is highly depends (dependent) on mangroves that provide seeds, food, clean water, and others (Hamilton and Snedaker, 1984).

Based on the research results of Fitri and Iswahyudi (2010), 49,89\% (36,064) of mangrove area in East Aceh is very critical, $39,72 \%(28,729$ ha), critical and only $10,43 \%(7,548)$ is not critical. The decline in mangroves has caused conflicts between communities and oil palm cultivation, causing pollution from residual waste of fertilizer and declining income of traditional fishing communities. If the encroachment continues, it is feared abrasion along the coast will threaten residential areas and the Banda Aceh-Medan route, North Sumatra.

Widespread mangrove absorption affects biodiversity and other resources and the functioning of the ecosystems. Damage to the mangrove ecosystem means disruption or loss of life support and economically advantagegous services provided by nature, which in turn means increased vulnerability, loss of income and livelihood activities and government revenues. Until now, mangroves is are often regarded as an unpleasant and low-value area (Dahdouh-Guebas et al., 2005). Ignorance of the value and benefits of mangrove ecosystems resulting in the damage or loss of these resources is not regarded as a loss, even the main a driver of mangrove system conversion to alternative use.

The great huge potential of mangrove must be conserved by allocating funds to help protect and enhance ecosystems. Therefore, it is important to know how many people are willing to participate actively in protecting and improving the mangrove ecosystem. This study aims to determine the amount of money that the members of Kuala Langsa village community are willing to pay to help preserve and repair the degraded mangroves.

\section{RESEARCH METHODS}

This research was conducted in the Kuala Langsa mangrove forest area, Aceh. The method used in this study is the willingness to pay (WTP) method. The willingness to pay (WTP) of a society is determined by using Contingen Valuation Method (CVM). CVM is a survey method used to ask the public about the price they are pay for commodities that do not have a market such as like environmental goods (Sure, 1997). The fundamental principle of this method is that for people who have the right but hidden preference for all kinds of environmental goods, it is assumed that they have the ability to turn that preference into monetary value.. Respondents were residents of Kuala Village, Langsa, Aceh who occupied the area around the Kuala Langsa mangrove forest. The number of respondents was 131 people from a total population of 669 households.

Willingness to pay is the price/value an individual is willing to pay to contribute to improvement improving the quality of the environment. WTP is calculated by based on how many individuals or a communities are ready to spend to help improve environmental conditions so that it they can meet the desired standards. WTP is the value of potential use of natural resources and environmental services (Hanley and Spash, 1993).

This method requires the respondents to only answer "yes" or "no" to the bid amount submiited. Initial offers vary between individuals to gather more information about the actual distribution of WTP. The decision as to whether or not the respondents are willing to pay for the cost of the restoration is based on the assumption that when people are faced with different possible options, they make an alternative choice that maximizes the benefits they receive. This model assumes that individuals are willing to pay for offer only if they benefit 
more from improved maintenance and conservation than otherwise.

WTP value obtained from the calculation of the middle value according to the formula (FAO, 2000) is as follows:

$$
\text { TWTP }=\sum_{i=1}^{n} \text { WTP }\left(\frac{n i}{N}\right) P
$$

$$
\begin{aligned}
& \text { TWTP : Respondent willingness to pay } \\
& \text { WTP : Respondent willingness } \\
& \text { (sample) to pay } \\
& \mathrm{P} \quad \text { : Population (KK) } \\
& \mathrm{N} \quad \text { : Total sample }
\end{aligned}
$$

\section{RESULTS AND DISCUSSION}

The value of existence is a value that is not generated from market institutions and has nothing to do with the productive asset function or production process directly or indirectly. The value of the existence of Kuala Langsa forest area is the value that the community allocated to the environment for its spiritual, aesthetic and cultural benefits. The value of mangrove is estimated by using Willingness to pay (WTP).

Kuala Langsa mangrove mangroves in recent years have suffered have experienced significant degradation pressure due to illegal logging by migrants from outside the region. In addition, development (ports, fishing vessels and temporary shelters conducted in mangrove leads to reduced forest area and increased pressure on mangroves. More over, there are plans to make the Kuala Langsa port as an industrial and shipping area of the State General Reserve (TCUN) by the Minister of Agrarian and Spacial Affairs and/Head of Land Agency to the city Langsa Regency with an area of $115 \mathrm{Ha}$ (Dedek, 2016) will accelerate the loss of mangrove forest.

Much of the mangrove areas that haves been converted into ports have not been followed by rehabilitation activities as subtitute for the lost of mangrove forests. This change has considerable damage on the surrounding mangroves due to loading and unloading activities at the port as well as the mobility and activities of ships dan fishery goods. In addition to water pollution caused by oil spills, garbage, and docking accelerate the loss of mangrove in Kuala Langsa and affect the process of sustainable development (Iswahyudi, 2013).
Environmental improvement activities in Kuala Langsa mangroves are conducted through a mangrove rehabilitation program run by the government. Based on information from the Ministry of Marine, Fisheries and Agriculture (Data 2015), rehabilitated mangrove areas have reached $90.64 \%$ of critical forest areas (755 ha from 855 ha of critical land) using APBN and DAK. Environmental improvement efforts should involve communities in mangrove areas so they have a moral responsibility to protect mangroves.

The number of respondents around the Kuala Langsa mangrove forest who are willing to pay for mangrove repairs was greater than those who are not willing to pay (see Table 1). Respondents who were willing to pay accounting for $85.496 \%$ of the total number of respondents. While those who are not willing to pay an estimated to $14.504 \%$ of the total number of respondents. Respondents who were not willing to pay for environmental improvement generally face poor economic conditions and consider obligations to be the responsibility of the local governments.

Table 1. Number of respondents in the mangrove forest Kuala Langsa Aceh that are willing/unwilling to pay

\begin{tabular}{lrr}
\hline & \multicolumn{2}{c}{ Respondent response } \\
\cline { 2 - 3 } & $\begin{array}{c}\text { Frequency } \\
(\mathrm{n})\end{array}$ & $\begin{array}{c}\text { Persentage } \\
(\%)\end{array}$ \\
\hline Willing to pay & 112 & 85,496 \\
Unwilling to pay & 19 & 14,504 \\
Total & 131 & 100,000 \\
\hline
\end{tabular}

The average sum of money that respondents of Kuala Mangrove areas are willing to pay is estimated to $\mathrm{Rp}$. $32,633.929 /$ month. The number of respondents and WTP value ini mangrove forest areas Kuala Langsa, Aceh is presented in Table 2. The aggregate WTP value is $\mathrm{Rp} 18,821,512.200,-$ per month or $\mathrm{Rp}$ $225,858,146,400$,- per year.

Based on the findings of this study, the value of WTP recommended for respondents ranged from $\mathrm{Rp}$. 5,000/month to Rp. 75,000/month. This is done to avoid the difficulty of respondents in giving the nominal value. The value of WTP value is quite high when compared with the income of respondents, which is estimated to reach Rp. 1,000,000/month. This value is much smaller than the regional wage (UMR) of Aceh province in 2016 
amounting to Rp. 2,118,500, -. Although Kuala Langsa respondents have relatively low incomes, most of them are still willing to provide a portion of their revenues for local the protection.

Tabel 2. Frequency of respondents and WTP value in mangrove forest area Kuala Langsa, Aceh

\begin{tabular}{lllr}
\hline $\begin{array}{l}\text { Value of } \\
\text { WTP }\end{array}$ & $\begin{array}{l}\text { Frequency } \\
\text { of } \\
\text { respondent }\end{array}$ & $\begin{array}{l}\text { Relative } \\
\text { frequency } \\
\text { (Pfi) }\end{array}$ & Total \\
\hline 5,000 & 1 & 0.009 & 44.463 \\
10,000 & 11 & 0.098 & 982.143 \\
20,000 & 12 & 0.107 & $2,142.857$ \\
30,000 & 60 & 0.536 & $16,071.429$ \\
50,000 & 24 & 0.214 & $10,741.286$ \\
75,000 & 4 & 0.036 & $2,678,571$ \\
\hline TOTAL & 112 & 1.000 & $32,633.929$ \\
\hline
\end{tabular}

The highest order value of WTP contributed by respondents Kuala Langsa is as follows: Rp. 30,000, or $53.571 \%$, Rp. 50,000 , or $21.429 \%$, Rp. 20,000, or $10.714 \%$, Rp. 10,000 or $9.821 \%$, Rp. 75,000 , or $3.571 \%$, and Rp. 5,000, or $0.893 \%$. The distribution of WTP value is shown in Figure 1. The average WTP value is Rp. $32,633.929$, rounded to Rp. 32.600, and may be determined by a combination of WTP or total Kuala Langsa WTP's. The number of respondents who are willing to pay is 112 of 131 respondents $(85,496 \%)$, and the number of families living in forest area is 669 Households, the combined WTP is Rp 18,821,512.200/ month or Rp 225,858,146.400 / per year.

The value of the WTP respondents of Kuala Langsa is greater than that of Angke Kapuk, Jakarta which is estimated to be 13,786.740/per month or Rp. 165,440.880/per year (Suryono, 2006). Utilization of WTP value of Cirahab springs is Rp. 5,240,617.805/year and the cost of ecological forest restoration is $\mathrm{Rp}$. 544.758,500/Ha /year (Merryna, 2009). However, the WTP value obtained in this study is smaller than that of the East coast of Surabaya ( $\operatorname{Rp~605.933,544,86)~whose~}$ mangrove areas $(471,15 \mathrm{ha})$ is smaller than that of Kuala Langsa (700 ha of forest) (Nuzuliah et al., 2014). While the average WTP for the value of mangrove conservation in Harmozgab Province amounted to 450,000 Rial / person with a payment rate of $92 \%$ (Paroun and Esmaeili, 2010).

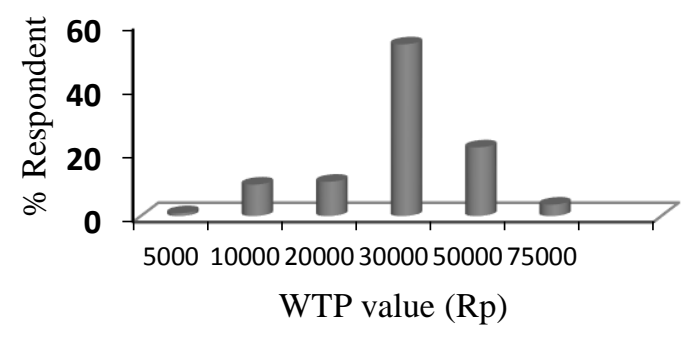

Figure 1. Distribution value of WTP respondents in mangrove forest area Kuala Langsa, Aceh

\section{CONCLUSION}

The value of WTP of Kuala Langsa Village is $18,821,512,200$ per month or Rp 225,858,146,400 per year. The amount of money paid by the respondents is strongly influenced by the perception and demography of the respondent population.

\section{REFERENCES}

Alongi, D. M. (1996). The dynamics of benthic nutrient pools and fluxes in tropical mangrove forests. $J$. Mar Res, Vol. 54:123-148.

Alongi, D.M. (2002). Present state and future of the world's mangrove forests. Environmental Conservation, Vol. 29 (3): 331-349.

Dahdouh-Guebas, F., L.P. Jayatissa, D. di Nitto; J.O.Bosire, D. L. Seen, N. Koedam. (2005). How effective were mangroves as a defense against the recent tsunami. Curr. Biol., Vol. 15: 443-447.

Dedek, (2016). Menteri ATR/BPN terbitkan izin pendayagunaan lahan di Kuala Langsa. https://www.goaceh.co/berita/baca/2016/05/22/m enteri-atrbpn-terbitkan-izin-pendayagunaa-lahandi-kuala-langsa. Akses 27 Juli 2016.

FAO. (2000). Applications of contingent valuation in developing countries. FAO Economic and Social Development, Paper 146. Food and Agriculture Organization of the United Nations, Viale Delle Terme di Caracalla, 00100 Rome, Italy.

Fitri, R. dan Iswahyudi. 2010. Evaluasi kekritisan lahan hutan mangrove di Kabupaten Aceh Timur. J. Hidrolitan, Vol. 1 (2):1-9.

Gunarto. (2004). Konservasi sebagai pendukung sumber hayati perikanan pantai. Jurnal Litbang Pertanian, Vol. 23 (1): 15-21. 
Hanley, N. and C.L. Spash. (1993). Cost Benefit Analysis and the Environment. Edward Elgar Publistions Limited. Hants-England.

Hamilton, L.S. dan S.C. Snedaker. (1984). Handbook of mangrove area management. Development of National Management Plant.

Iswahyudi. (2013). Tingkat kekritisan arah pengembangan ekosistem mangrove di Kota Langsa. Jurnal Ekonomi dan Pembangunan Vol. 4 (1):20-29.

Merryna, A. (2009). Analisis willingness to pay masyarakat terhadap pembayaran jasa lingkungan mata air Cirahab (Desa Curug Goong, Kecamatan Padarincang, Kabupaten Serang, Banten). Departemen Ekonomi Sumberdaya dan Lingkungan Fakultas Ekonomi dan Manajemen Institut Pertanian Bogor,

Nuzulia, D.I. (2014). Analisis ekonomi hutan mangrove di pantai timur Kota Surabaya, Provinsi Jawa Timur. Universitas Airlangga, Surabaya.

Ong, J.E., W.K. Gong., C.H. Wong, Z.H. Din dan B. Kjerfve. (1991). Characterization of a Malaysian mangrove estuary. Estuaries, Vol. 14 (1): 38-48.

Paroun,S. dan Esmaeili, A.A.KS. (2010). Non market valuation of mangrove forest in Hormozgan Province. Journal of economics and agriculture development, Vol. 24 (2): 162-168.

Pendleton, 1., D. C. Donato, B. C. Murray, S. Crooks, W. A. Jenkins, S. Sifleet, C. Craft, J. W. Fourqurean, J. B. Kauffman, Nu'ria Marba, P.Megonigal, E. Pidgeon, D. Herr, D. Gordon, and A. Baldera. (2012). Estimating global "Blue Carbon" emissions from conversion and degradation of vegetated coastal ecosystems.. PLoS ONE 7(9): e43542.

Primavera, J.H. (1997). Socio-economic impacts of shrimp culture. Aquaculture Research, Vol. 28. 815-827.

Sarhan, M. (2014). The Economic Valuation of Mangrove Forest Ecosystem Services: A Review. Environment Department, Environmental Valuation, University of York.

Sasekumar, A., Chong, V.C. and H.R. Singh. (1994).The physical and chemical characteristics of the Matang Mangrove waters. In: Sudara, S., Wilkinson, C.R. \& Chou, L.M. (eds.) Proceedings, Third-ASEAN-Australia Symposium on Living Coastal Resources, Vol. 2: Research
Papers, Chulalongkorn University, Bangkok Thailand, pp. 446-453.

Soemodihardjo, S. and I. Soerianegara. (1989). The status of mangrove forests in Indonesia. In: Soerianegera I, Zamora PM, Kartawinata K, Umaly RC, Tjitrosomo S, Sitompul DM, Rosalina U (Eds.). Proceedings symposium on mangrove management: its ecological and economic considerations: 73-114. Bogor: SEAMEOBOTROP.

Sukardjo, S. (1987). Tanah dan status hara di hutan mangrove Tiris, Indramayu, Jawa Barat. Rimba Indonesia, Vol. XXI (2-4): 12-23.

Suryono, T. 2006. Penilaian Ekonomi Lingkungan Terhadap Konversi Hutan Mangrove Menjadi Tambak dan Pemukiman (Studi Kasus di Hutan Angke Kapuk Jakarta Utara). Tesis. Bogor: Sekolah Pascasarjana Institut Pertanian Bogor. 